\title{
UPAYA PENINGKATAN HASIL BELAJAR TEMA BERBAGAI \\ PEKERJAAN MELALUI MODEL DISCOVERY LEARNING \\ SISWA KELAS 4 SDN KUTOHARJO 01 PATI \\ KABUPATEN PATI SEMESTER 1 \\ TAHUN AJARAN 2014-2015
}

\author{
Rumini \\ ruminiaja52@gmail.com \\ SDN Kutoharjo 01 Pati - Kabupaten Pati \\ Naniek Sulistya Wardani \\ wardani.naniek@gmail.com \\ Program Studi PGSD FKIP - Universitas Kristen Satya Wacana
}

\begin{abstract}
ABSTRAK
Tujuan penelitian ini adalah untuk mengetahui apakah peningkatan hasil belajar tema berbagai pekerjaan dapat diupayakan melalui pendekatan discovery learning siswa kelas 4 SDN Kutoharjo 01 Pati semester 1 tahun ajaran 2014-2015. Jenis penelitian ini adalah penelitian tindakan kelas (PTK). Model PTK yang digunakan model spiral dari C. Kemmis \& Mc Taggart dengan menggunakan 2 siklus, masing-masing siklus terdiri dari 3 tahap yakni, 1) perencanaan tindakan 2) pelaksanaan tindakan dan observasi dan 3) refleksi. Subjek penelitian ini adalah siswa kelas 4 SDN Kutoharjo 01 Pati Kabupaten Pati yang berjumlah 26 siswa. Teknik pengumpulan data adalah teknik tes dan teknik non tes. Instrumen penelitian dengan menggunakan butir soal dan lembar observasi.Teknik analisis yang digunakan adalah teknik deskriptif komparatif yakni membandingkan hasil belajar tema berbagai pekerjaan berdasarkan ketuntasan belajar, skor minimal, skor maksimal dan skor rata-rata pra siklus, siklus 1dan siklus 2. Hasil penelitian menunjukkan bahwa peningkatan hasil belajar tema Berbagai Pekerjaan dapat diupayakan melalui pendekatan discovery learning siswa kelas 4 SDN Kutoharjo 01 Pati Kabupaten Pati semester 1 tahun ajaran 2014-2015 terbukti. Hal ini ditunjukkan oleh meningkatnya hasil belajar tema berbagai pekerjaan dari pra siklus, siklus 1 ke siklus 2. 1) Hasil belajar berdasarkan ketuntasan belajar dengan $\mathrm{KKM} \geq 80$ meningkat dari pra siklus ke siklus 1 dan siklus 2 yakni dari $0 \%, 69,23 \%$ dan $88,46 \%$; 2) Hasil belajar berdasarkan skor minimal dari pra siklus ke siklus 1 dan siklus 2 yakni dari 20: 53: 66; 3) Hasil belajar berdasarkan skor maksimal dari pra siklus ke siklus 1 dan siklus 2 yakni 45; 92; 100; 4) Hasil belajar berdasarkan skor rata-rata dari pra siklus ke siklus 1 dan siklus 2 yakni dari 37,1: 78,5: 88,0. PTK ini dikatakan berhasil, yang ditunjukkan oleh besarnya persentase siswa yang mencapai hasil belajar tema berbagai pekerjaan tuntas belajar dengan $\mathrm{KKM} \geq 80$, mencapai 88,46\% lebih tinggi dari $80 \%$ dari 26 siswa yang ditetapkan dalam indikator keberhasilan PTK.
\end{abstract}

Kata kunci: Pembelajaran Tematik, Pendekatan Pembelajaran Discovery Learning dan Hasil Belajar 


\section{PENDAHULUAN}

\section{Latar Belakang Masalah}

Guru memiliki peran yang sangat penting dalam menentukan keberhasilan pembelajaran, seperti yang ditegaskan dalam UU RI No. 20/2003 tentang Sistem Pendidikan Nasional pasal 1 butir 1 menyatakan bahwa "Pendidikan adalah usaha sadar dan terencana untuk mewujudkan suasana belajar dan proses pembelajaran". Untuk itu, Kurikulum 2013 dirancang dengan karakteristik untuk mengembangkan keseimbangan antara pengembangan sikap spiritual dan sosial, rasa ingin tahu, kreativitas, kerja sama dengan kemampuan intelektual dan psikomotorik. Pembelajaran di kelas perlu didesain dengan melibatkan siswa untuk belajar.

Dalam pelaksanaan pembelajaran siswa kelas 4 SDN Kutoharjo 01 Pati Kabupaten Pati pada awal semester 1 tahun ajaran 2014-2015, nampak ada permasalahan pembelajaran. SDN Kutoharjo 01 Pati telah menetapkan untuk menggunakan kurikulum 2013 dalam pembelajaran. Dalam pelaksanaan pembelajaran tematik, nampak penyajian materi pembelajaran tematik tidak terintegrasi antara disiplin ilmu yang digunakan, sehingga pembelajaran yang diberikan mempelajari matematika dulu, kemudian Bahasa Indonesia, IPA dan IPS, yang dibungkus dalam tema tertentu. Proses belajar yang berlangsung, hampir seluruh waktu digunakan oleh guru untuk memberikan penjelasan, tanpa melibatkan siswa untuk belajar, kecuali mendengarkan saja. Nampak bahwa pembelajaran tidak didesain dengan menggunakan pendekatan pembelajaran tertentu seperti menggunakan pendekatan discovery learning (PDL). Guru menggunakan metode pembelajaran ceramah dan metode penugasan yang berupa pemberian pekerjaan rumah (PR).

Pengukuran hasil belajar didasarkan aspek kognitif saja, tanpa memberikan pengukuran terhadap aspek sikap dan aspek ketrampilan siswa. Hasil belajar siswa berdasarkan skor tes untuk 4 mata pelajaran dengan $\mathrm{KKM} \geq 80$, ketuntasan Bahasa Indonesia sebesar 57,69\%, ketuntasan Matematika 30,77\%, ketuntasan IPA 61,54\% dan ketuntasan IPS sebesar 65,38\%. Apabila ke 4 mata pelajaran diambil rata-rata skor tes sebesar 74,1, dibawah skor KKM yakni 80. Apalagi, jika hasil belajar siswa diukur dengan aspek sikap, pengetahuan dan ketrampilan, seluruh siswa tidak tuntas. Kondisi belajar ini, diperkuat dengan fenomena belajar di kelas, siswa tidak berani bertanya, siswa tidak menjawab atas pertanyaan guru dan siswa hanya duduk diam, mendengarkan dan menyimak penjelasan guru. Kondisi ini diperparah dengan sikap guru yang tidak nampak mendorong siswa untuk bertanya ketika diberikan kegiatan diskusi, tidak nampak guru membimbing dan mendampingi siswa ketika siswa berdiskusi. 
Dalam pembelajaran, guru meminta siswa untuk membentuk kelompok, melakukan diskusi untuk mengerjakan soal-soal yang terdapat dalam buku teks. Pada saat membentuk kelompok diskusi, guru tidak membagi siswa berdasarkan tingkat kemampuan akademik dan keaktifan masing-masing siswa, melainkan siswa diminta untuk membentuk kelompok dengan anggota kelompok sesuai tempat duduk yang saling berdekatan. Kelompok yang terbentuk bersifat homogen dan siswa yang pandai tergabung dalam satu kelompok, sehingga mendominasi jalannya proses diskusi. Kurangnya pengawasan dan teknik pengelolaan kelas saat diskusi berlangsung membuat beberapa siswa bermain dengan teman sebangkunya, bahkan terdapat beberapa siswa yang keluar masuk ruang kelas dengan alasan yang kurang jelas. Keadaan ini jika dibiarkan terlalu lama akan membuat siswa lainnya enggan dan tidak berkonsentrasi saat mengikuti pembelajaran. Pengukuran hasil belajar yang dilakukan guru berfokus pada aspek pengetahuan saja. Ketrampilan proses yang dapat menumbuhkembangkan keterampilan siswa dalam berpikir, bertindak dan menerapkan pengetahuan yang diperoleh dari sekolah pada lingkungan sekitarnya tidak dilakukan pengukuran.

Mendasarkan pada permasalahan yang ada, maka permasalahan yang dapat dirumuskan, adalah apakah peningkatan hasil belajar tema berbagai pekerjaan dapat diupayakan melalui pendekatan discovery learning siswa kelas 4 SDN Kutoharjo 01 Pati Kabupaten Pati semester 1 tahun ajaran 2014-2015.

Kurikulum 2013 menekankan pembelajaran untuk siswa SD menggunakan pembelajaran tematik integratif. Pembelajaran tematik integratif merupakan pembelajaran yang memiliki karakteristik yang berpusat pada peserta didik dan memberi pengalaman langsung pada peserta didik. Menurut Atan (2009: 76-77) pembelajaran tematik integratif dapat diimplementasikan melalui: 1) Integrasi keterampilan di sejumlah mata pelajaran; (2) asimilasi berbagai konten dalam mata pelajaran; 3) integrasi nilai dalam mata pelajaran; dan 4) Integrasi pengetahuan dan praktik. Implementasi pembelajaran tematik adalah dengan merakit atau menggabungkan sejumlah konsep beberapa mata pelajaran yang berbeda dalam suatu tema, sehingga peserta didik tidak belajar konsep dasar secara parsial. Dengan demikian pembelajarannya memberikan makna yang utuh kepada peserta didik.

Dalam materi Bahan Ajar Pengelolaan Pembelajaran Tematik Terpadu, Kemendikbud (2013: 15) disebutkan ciri-ciri pembelajaran tematik adalah berpusat pada peserta didik, memberi pengalaman langsung pada peserta didik, pemisahan antar mata pelajaran tidak begitu jelas, menyajikan konsep dari berbagai muatan mata pelajaran dalam suatu proses pembelajaran, bersifat luwes, hasil pembelajaran dapat berkembang sesuai dengan minat dan kebutuhan siswa, holistik, artinya suatu peristiwa yang menjadi pusat perhatian dalam pembelajaran tematik diamati dan dikaji dari beberapa mata pelajaran sekaligus, tidak dari sudut pandang yang 
terkotak-kotak, bermakna, artinya pengkajian suatu fenomena dari berbagai macam aspek memungkinkan terbentuknya semacam jalinan skemata yang dimiliki peserta didik, otentik, artinya informasi dan pengetahuan yang diperoleh bersifat otentik, aktif, artinya siswa terlibat langsung dalam proses pembelajaran mulai dari perencanaan, pelaksanaan hingga penilaian dan bertema seperti tema berbagai pekerjaan. Oleh karena, desain pembelajaran yang melibatka siswa menjadi penting. Pemetaan kompetensi dasar dalam pembelajaran tematik Berbagai Pekerjaan yang digunakan dalam penelitian siklus 1 disajikan secara rinci melalui gambar 1 di halaman berikut.

Pendekatan discovery learning (PDL) merupakan pendekatan pembelajaran yang sesuai dengan karakteristik pembelajaran tematik. Hal ini dikarenakan $P D L$ merupakan sebuah pendekatan pembelajaran yang berpusat pada siswa, guru memberikan kesempatan dan kebebasan kepada siswa untuk menemukan, menggali dan mengkonstruksi pengetahuannya sendiri, sehingga siswa dapat lebih mengerti dan mudah memahami materi pembelajaran. Dengan belajar menemukan sendiri, siswa akan lebih dapat memahami dan mengingat konsep dan pengetahuan yang dipelajari sendiri, sehingga hasil belajar siswa dapat meningkat.

Menurut Sund dalam Roestiyah (1998: 22), discovery learning adalah proses mental siswa untuk mampu mengasimilasikan sesuatu konsep atau prinsip. Maksud dari proses mental tersebut antara lain: mengamati, mencerna, mengerti, mengklasifikasikan, membuat dugaan, menjelaskan, mengukur, membuat kesimpulan, dan sebagainya. Piaget menyatakan bahwa siswa harus berperan secara aktif di dalam belajar di kelas. Untuk itu Bruner memakai cara dengan menyebutnya discovery learning, yaitu siswa mengorganisasikan bahan yang dipelajari dalam suatu bentuk akhir.

Menurut Bell dalam Sutrisno (2008: 67) menyatakan bahwa belajar penemuan (discovery) adalah belajar yang terjadi sebagai hasil dari siswa memanipulasi, membuat struktur dan mentransformasikan informasi untuk menemukan informasi baru. Berdasarkan pendapat para ahli diatas, dapat disimpulkan bahwa pendekatan discovery learning (penemuan), adalah sebuah pendekatan pembelajaran yang dapat membantu siswa untuk mendapatkan ide, konsep, dan ketrampilan yang dipelajari sebelumnya untuk mendapatkan pengetahuan baru. Sebagai model pembelajaran, pendekatan discovery learning menempatkan guru sebagai fasilitator, dengan cara membimbing siswa untuk berfikir sendiri, untuk menemukan prinsip umum berdasarkan bahan atau topik yang disediakan oleh guru. 


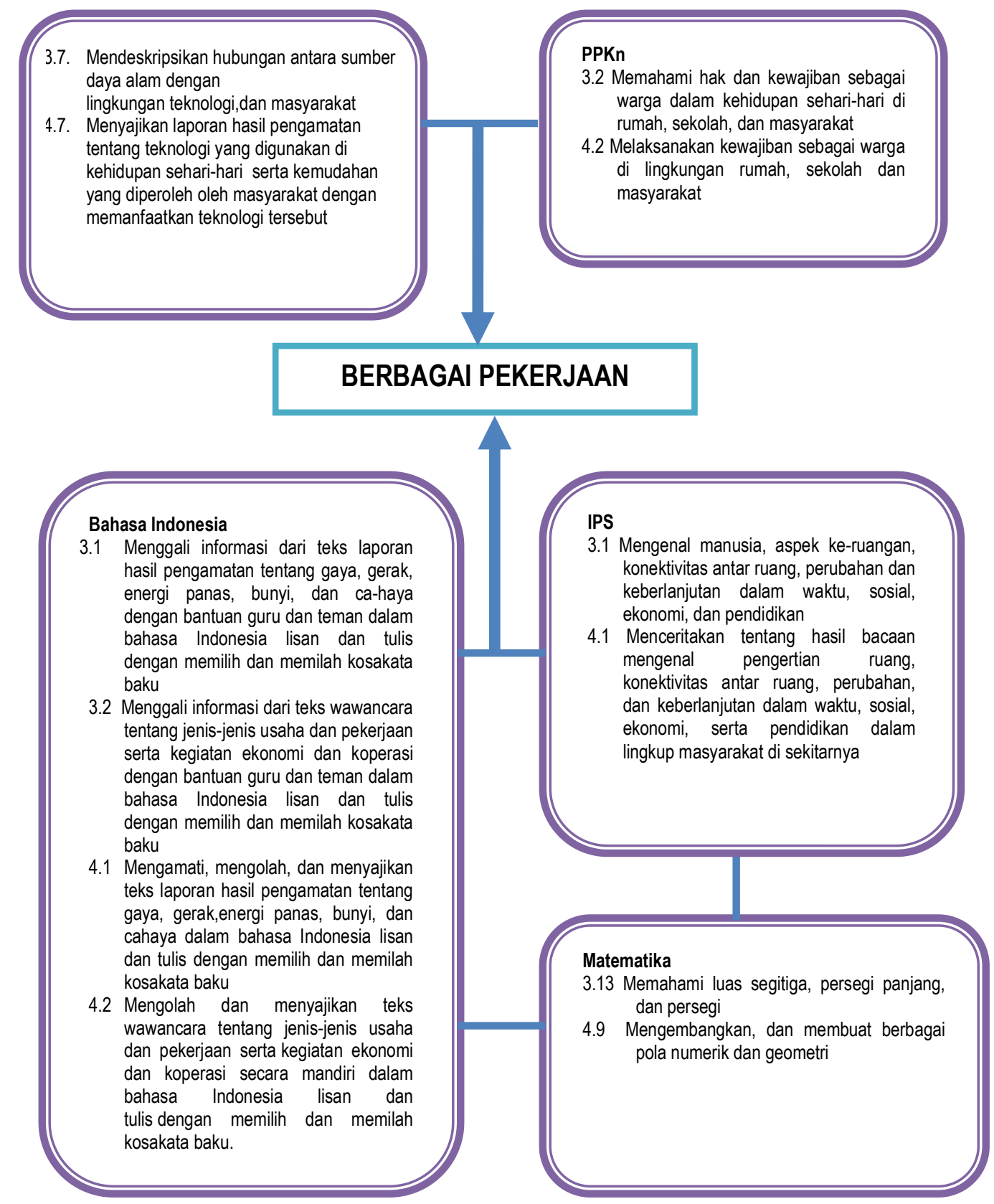

Sumber: Buku Guru SD/MI Kelas 4 Tema Berbagai Pekerjaan

\section{Gambar 1}

\section{Pemetaan Kompetensi Dasar KI-3 dan KI-4 Tema Berbagai Pekerjaan}

Menurut Kemendikbud, (2013: 23) menyatakan, dalam aplikasi metode discovery learning seorang guru harus dapat menempatkan siswa pada kesempatankesempatan dalam belajar lebih mandiri. Proses belajar akan berjalan dengan baik 
dan kreatif jika guru memberikan kesempatan kepada siswa untuk menemukan suatu konsep, teori, aturan, atau pemahaman melalui contoh-contoh yang ia jumpai dalam kehidupannya. Kemudian melalui kegiatan-kegiatan tersebut siswa akan menguasai konsep-konsep yang ditemukan dan menerapkannya dalam kehidupan.

Brunner (Suryobroto, 2009: 69) mengemukakan, bahwa persiapan guru dalam mengaplikasikan pendekatan discovery learning di kelas, adalah menentukan tujuan pembelajaran, melakukan identifikasi karakteristik siswa, memilih materi pelajaran, menentukan topik-topik yang harus dipelajari siswa secara induktif, mengembangkan bahan-bahan belajar, mengatur topik-topik pelajaran dari yang sederhana ke kompleks, melakukan penilaian proses dan hasil belajar siswa.

Langkah-langkah pendekatan discovery learning menurut Syah (Agus N. Cahyo, 2013: 123-127) adalah sebagai berikut:

1. Stimulation, siswa dihadapkan sesuatu yang menimbulkan kebingungannya,

2. Problem statement. Guru memberi kesempatan kepada siswa untuk mengidentifikasi agenda-agenda masalah yang relevan dengan bahan pelajaran.

3. Data collection. Guru memberi kesempatan kepada siswa untuk mengumpulkan informasi yang relevan untuk membuktikan hipotesis.

4. Data processing merupakan kegiatan mengolah data dan informasi yang telah diperoleh siswa melalui wawancara, observasi, dsb lalu ditafsirkan.

5. Verification, siswa melakukan pemeriksaan untuk membuktikan hipotesis

6. Generalization adalah proses menarik kesimpulan.

Dengan demikian, langkah-langkah kegiatan pembelajaran penemuan (discovery learning) adalah Siswa menerima sebuah pertanyaan yang merangsang siswa berfikir, menyimak penjelasan guru dan mengamati gambar atau teks bacaan untuk mengumpulkan informasi, merumuskan masalah, siswa membuat hipotesis, mengumpulkan data, mengolah data, meverifikasi, membuat generalisasi dan presentasi hasil diskusi dan siswa lain memberikan tanggapan.

Hasil belajar menurut Briggs yang dikutip Taruh (2003: 17) adalah seluruh kecakapan dan hasil yang dicapai melalui proses belajar mengajar di sekolah yang dinyatakan dengan angka-angka atau nilai-nilai berdasarkan tes hasil belajar. Rasyid (2008: 9) berpendapat bahwa jika di tinjau dari segi proses pengukurannya, kemampuan seseorang dapat dinyatakan dengan angka. Dengan demikian, hasil belajar siswa dapat diperoleh guru dengan terlebih dahulu memberikan seperangkat tes kepada siswa untuk menjawabnya. Hasil tes belajar siswa, akan memberikan gambaran informasi tentang kemampuan dan penguasaan siswa pada suatu materi pelajaran yang kemudian dikonversi dalam bentuk angka-angka. Menurut Dick dan Reiser yang dikutip oleh Sumarno, (2011: 176) mengemukakan pengertian hasil belajar yaitu:

"hasil belajar merupakan kemampuan-kemampuan yang dimiliki siswa sebagai hasil kegiatan pembelajaran, yang terdiri atas empat jenis, yaitu: (1) 
pengetahuan, (2) keterampilan intelektual, (3) keterampilan motor, dan (4) sikap."

Pendapat yang lain dikemukakan oleh Bloom dan Kratwohl (dalam Usman, 1994: 29) bahwa hasil belajar dapat dikelompokkan ke dalam tiga kategori yaitu ranah kognitif, afektif, dan psikomotor.Merujuk dari pendapat para ahli diatas dapat disimpulkan bahwa, hasil belajar adalah total skor dari aspek kognitif, afektif dan psikomotor yang dicapai melalui proses belajar.

Keberhasilan pembelajaran pada ranah kognitif dan psikomotor dalam Wardani Naniek Sulistya, dkk., (2012: 4.29 - 4.32) dipengaruhi oleh kondisi afektif peserta didik. Peserta didik yang memiliki minat belajar dan sikap positif terhadap pelajaran akan merasa senang mempelajari mata pelajaran tertentu, sehingga dapat mencapai hasil pembelajaran yang optimal. Oleh karena itu semua pendidik harus mampu membangkitkan minat semua peserta didik untuk mencapai kompetensi yang telah ditentukan. Selain itu ikatan emosional sering diperlukan untuk membangun semangat kebersamaan, semangat persatuan, semangat nasionalisme, rasa sosial, dan sebagainya. Masalah afektif dirasakan penting oleh semua orang, namun implementasinya masih kurang, untuk itu perlu dikembangkan acuan pengembangan perangkat penilaian ranah afektif serta penafsiran hasil pengukurannya. Untuk mengetahui hasil belajar seseorang dapat dilakukan dengan melakukan pengukuran. Pengukuran diartikan sebagai kegiatan atau upaya yang dilakukan untuk memberikan angka-angka pada suatu gejala atau peristiwa, atau benda (Wardani Naniek Sulistya dkk., 2012: 4.24).

Alat yang digunakan untuk mengukur disebut instrumen. Teknik pengukuran hasil belajar ada dua. Menurut Wahidmurni, dkk. (2010: 28), teknik pengukuran dibedakan menjadi dua, yakni teknik tes dan teknik non tes. Tes menurut Lee J.Cronbach dalam bukunya berjudul Essential of Psycologycal Testing mengemukakan, tes merupakan suatu prosedur yang sistematis untuk membandingkan tingkah laku dua orang atau lebih. Sedangkan menurut Suryanto Adi, dkk., (2009: 89-101) tes adalah seperangkat pertanyaan atau tugas yang direncanakan untuk memperoleh informasi tentang trait atau sifat atau atribut pendidikan yang setiap butir pertanyaan tersebut mempunyai jawaban atau ketentuan yang dianggap benar.

Menurut Wardani Naniek Sulistya (2012: 144-145), pengelompokkan jenisjenis tes berdasarkan cara mengerjakan, dapat dibedakan menjadi 3 yakni tes tertulis (berbentuk tes objektif, pilihan ganda, jawaban singkat atau isian, benar salah, dan bentuk menjodohkan dan berbentuk tes uraian); tes lisan dan tes perbuatan. Jenis tes berdasarkan bentuk jawabannya, dapat dibedakan menjadi 3 yakni tes isian (essaytype test); tes jawaban pendek; dan tes objektif. Teknik non tes merupakan teknik penilaian atau evaluasi hasil belajar peserta didik yang dilakukan dengan tanpa menguji peserta didik melainkan dilakukan melalui observasi, wawancara, skala, dan portofolio (Wardani Naniek Sulistya, dkk. 2012: 47). 
Penelitian yang relevan dilakukan Fiskasari Tri Pratiwi tahun 2014, yang berjudul "Upaya Peningkatan Hasil Belajar Tematik Keindahan Alam Negeriku Melalui Pendekatan Discovery Siswa Kelas 4 SDN Kutowinangun 09 Salatiga Semester 2 Tahun 2013/2014". Hasil penelitian ini menunjukkan, adanya peningkatan hasil belajar yang nampak dari meningkatnya skor ketuntasan belajar siswa, skor rata-rata pra siklus sebesar 35,21, siklus 1 meningkat menjadi 79,80, siklus 2 menjadi 90,17 dan pada siklus 3 skor rata-rata meningkat menjadi 94,00. Ketuntasan belajar pra siklus, belum ada seorang siswa yang tuntas $(0 \%)$, siklus 1 meningkat menjadi 33,33\%, siklus 2 menjadi 80\%, dan siklus 3 meningkat 93,33\%. Skor minimal yang diperoleh siswa pra siklus sebesar 30, siklus 1 meningkat menjadi 57,5, siklus 2 meningkat menjadi 65 dan siklus 3 sebesar 85. Skor maksimal pra siklus adalah sebesar 40, siklus 1 meningkat menjadi 95, siklus 2 dan siklus 3 skor maksimal adalah sebesar 100. Kelebihan yang dicapai dalam penelitian ini, adalah keberhasilan dalam melatih siswa untuk belajar mandiri dan otonom. Kekurangan penelitian ini adalah, siswa masih cukup kesulitan melakukan pengumpulan informasi dan data-data.

Penelitian yang relevan juga dilakukan oleh Muliani, tahun 2014 dengan judul "Upaya Peningkatan Kreativitas Belajar IPA Melalui Pendekatan Discovery Learning Siswa Kelas 4 SD Persiapan 300 Waisai Raja Ampat Papua Semester 1 Tahun 2014/2015". Pada penelitian ini membuktikan bahwa, penggunaan pendekatan pembelajaran discovery, efektif untuk meningkatkan kreatifitas belajar IPA tentang bentuk-bentuk daun. Hal ini ditunjukkan oleh peningkatan kreativitas siswa pada siklus 1, rasa ingin tahu (RIT) dari $31,25 \%$ meningkat menjadi $43,75 \%$, toleransi terhadap resiko (TO) dari $25 \%$ meningkat menjadi $37 \%$, dan keterbukaan terhadap pengalaman dan pengetahuan (KT) dari 28,13\% meningkat menjadi 50\%. Kelebihan penelitian ini berhasil meningkatkan kreativitas belajar IPA siswa kelas 4 dari kreativitas yang sedang sampai tinggi, Kekurangan penelitian ini, adalah penilaian menekankan aspek pengetahuan saja.

\section{Kerangka Pikir}

Pembelajaran yang telah berlangsung adalah pembelajaran yang berpusat pada guru dan tidak pernah melibatkan siswa, hasil belajar siswa diukur hanya melalui tes atau aspek kognitif saja yang diukur. Oleh karena itu, perbaikan pembelajaran perlu dilakukan. Upaya yang dilakukan untuk meningkatkan hasil belajar adalah melalui mendesain pembelajaran dengan menggunakan pendekatan discovery learning

Pendekatan discovery learning adalah sebuah pendekatan pembelajaran tema Berbagai Pekerjaan sub tema Barang dan Jasa untuk mencapai muatan IPS KD 3.1, muatan Matematika KD 3.13, muatan IPA KD 3.7, dan muatan Bahasa Indonesia KD 3.3, dengan langkah mengamati gambar tentang barang dan jasa, menyimak 


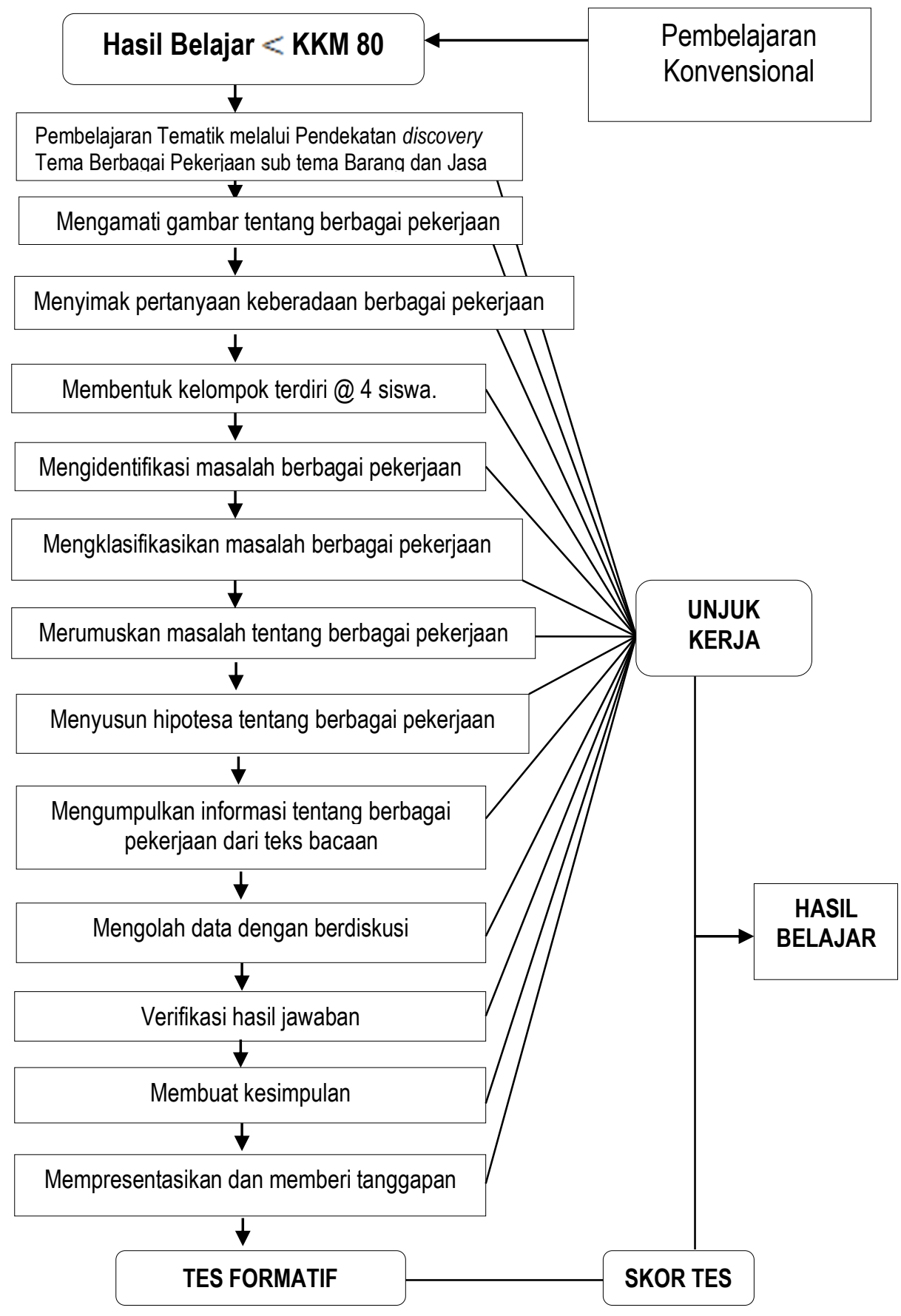

Gambar 2

Kerangka Pikir Peningkatan Hasil Belajar Tema Berbagai Pekerjaan Melalui Pendekatan Discovery Learning 
pertanyaan tentang berbagai pekerjaan, membentuk kelompok terdiri @ 4 siswa, mengidentifikasi masalah berbagai pekerjaan, mengklasifikasikan masalah berbagai pekerjaan, merumuskan masalah tentang berbagai pekerjaan, menyusun hipotesa tentang berbagai pekerjaan, mengumpulkan informasi tentang berbagai pekerjaan dari teks bacaan, mengolah data dengan berdiskusi, verifikasi hasil jawaban, membuat kesimpulan dan mempresentasikan dan memberi tanggapan.

Pembelajaran tematik digunakan untuk mencapai KD-KD yang diharapkan, sehingga pengukurannya adalah menyeluruh, untuk itu pengukuran hasil belajar meliputi aspek kognitif, afektif dan psikomotor, seperti gambar 2 berikut ini.

Hipotesis tindakan dalam penelitian ini adalah, peningkatan hasil belajar tema berbagai pekerjaan diduga dapat diupayakan melalui pendekatan discovery learning siswa kelas 4 SDN Kutoharjo 01 Pati Kabupaten Pati semester 1 tahun ajaran 2014/2015.

\section{METODE PENELITIAN}

Penelitian ini dilakukan di SDN Kutoharjo 01 Pati Kabupaten Pati pada semester 1 tahun ajaran 2014/2015. Subjek penelitian adalah siswa kelas 4 yang berjumlah 26 siswa, terdiri dari 14 siswa laki-laki dan 12 siswa perempuan.

Dalam penelitian ini terdapat dua variabel yaitu pendekatan discovery learning, dan hasil belajar tematik. Pendekatan discovery learning adalah pendekatan pembelajaran tema Berbagai Pekerjaan dengan langkah-langkah; menyimak pertanyaan tentang berbagai pekerjaan, membentuk kelompok terdiri @ 4 siswa, mengidentifikasi masalah berbagai pekerjaan, mengklasifikasikan masalah berbagai pekerjaan, merumuskan masalah tentang berbagai pekerjaan, menyusun hipotesis tentang Barang dan Jasa, mengumpulkan informasi jenis pekerjaan yang menghasilkan barang dan jasa, mengolah data dengan berdiskusi hasil pengumpulan informasi, membuat pembuktian dari hipotesa yang diajukan, dan menarik kesimpulan, mempresentasikan dan memberi tanggapan. Hasil belajar adalah besarnya skor yang diperoleh dari skor unjuk kerja dan skor tes.

Jenis penelitian ini adalah penelitian tindakan kelas (PTK) dengan model spiral yang dikemukakan oleh Stephen Kemmis dan Robin Mc.Taggart. Prosedur PTK menggunakan dua siklus yang masing-masing terdiri dari tiga tahap yakni, perencanaan, pelaksanaan tindakan dan observasi, refleksi. Tahapan kegiatan pada setiap siklus secara rinci dijelaskan melalui gambar 3 berikut ini. 


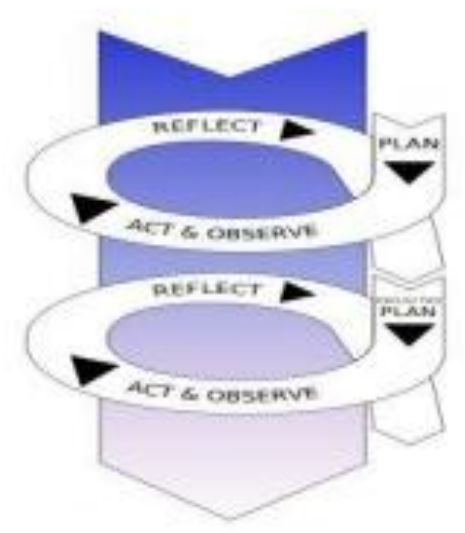

Gambar 3

PTK Model Spiral dari Stephen Kemmis dan Robin Mc.Taggart

Jenis data penelitian berupa data primer. Teknik pengumpulan data menggunakan teknik tes dan non tes dengan menggunakan instrumen penilaian berupa butir tes dan lembar observasi.

Uji instrumen penelitian

Sebuah instrumen dikatakan valid, apabila dapat mengungkap data dari variabel yang diteliti secara tepat (Arikunto, 2006: 168). Teknik yang digunakan untuk mengetahui kesejajaran validitas, adalah teknik korelasi product moment Pearson (Arikunto, 2006: 170), dengan rumus angka kasar.

$$
r_{x y}=\frac{n \sum x y-\left(\sum x\right)\left(\sum y\right)}{\left\{\sum x^{2}-\left\{\sum x^{2}\right)\right\}\left\{n \sum y^{2}-\left\{\sum y^{2}\right)\right\}}
$$

Keterangan:

$\mathrm{r}_{\mathrm{xy}} \quad=$ Koefisien korelasi pearson

$\mathrm{x} \quad=$ Variabel bebas

$\mathrm{y} \quad=$ Variabel terikat

$\mathrm{n} \quad=$ Jumlah data

Hasil uji validitas dengan bantuan SPSS 16,0 for windows untuk 20 butir soal tsiklus 1, nampak bahwa ada 4 (empat) butir soal yang tidak valid, karena koefisien korelasi yang didapatkan $<0,20$, dan tidak digunakan dalam penelitian, (butir soal nomor 2, 6, 15 dan 18). Butir soal yang koefisien korelasinya $\geq 0,20$, ada 16 butir soal tdan dinyatakan valid, dan digunakan dalam penelitian.

Uji validitas terhadap instrumen butir soal siklus 2, nampak terdapat 17 butir soal dinyatakan valid dan 3 butir soal tidak valid ( nomor 4, 14 dan 15).

Menurut Sudjana (2011:16), reliabilitas alat penilaian adalah ketetapan atau keajegan alat tersebut dalam menilai apa yang dinilainya. Artinya, kapanpun alat penilaian tersebut digunakan akan memberikan hasil yang relatif sama. Untuk 
menentukan koefisien reliabilitas soal pilihan ganda menggunakan rumus K R.20. Rumus reliabilitas dengan KR.20 (Sugiyono. 2006:278) adalah:

$$
r_{i=} \frac{k}{(k-1)}\left\{\frac{s_{t}^{2}-\sum p_{i} q_{i}}{s_{t}^{2}}\right\}
$$

Keterangan:

$\mathrm{k}$ = Jumlah butir soal dalam instrumen

$\mathrm{p}_{\mathrm{i}} \quad=$ Proporsi banyaknya subjek yang menjawab pada butir soal 1

$\mathrm{q} 1=1-\mathrm{pi}$

$\mathrm{S}_{\mathrm{t}}^{\mathrm{Z}}=$ Varians total

Uji reliabilitas butir soal tes dinyatakan dalam Cronbach's Alpha. Dalam buku Evaluasi Proses dan Hasil Belajar yang ditulis oleh Wardani Naniek Sulistya dan Slameto (2012:88) seperti tersaji melalui tabel 1 berikut:

\section{Tabel 1}

Indeks Reliabilitas

\begin{tabular}{|c|c|c|}
\hline No & Indeks & Interpretasi \\
\hline 1 & $0,80-1,00$ & Sangat reliabilitas \\
\hline 2 & $0,60-0,80$ & Reliabilitas \\
\hline 3 & $0,40-0,60$ & Cukup reliabel \\
\hline 4 & $0,20-0,40$ & Agak reliabel \\
\hline
\end{tabular}

Sumber: Wardani Naniek Sulistya dan Slameto (2012:88)

Hasil uji reliabilitas butir soal siklus 1 dan siklus 2 sebesar 0,826 , dan 0.843 , artinya sangat reliabilel, karena berada pada $0,80 \leq \alpha \leq 1,00$.

Indikator Keberhasilan. Penelitian ini dikatakan berhasil, jika jumlah siswa yang mencapai hasil belajar tematik Berbagai Pekerjaan siswa kelas 4 dengan KKM $\geq 80$ mencapai $\geq 80 \%$ dari seluruh siswa

Teknik Analisis Data yang digunakan dalam penelitian ini adalah deskriptif komparatif yaitu dengan membandingkan hasil belajar tema berbagai pekerjaan berdasarkan ketuntasan belajar, skor minimal, skor maksimal dan skor rata-rata dari pra siklus, siklus 1 dan siklus 2 .

\section{HASIL PENELITIAN DAN PEMBAHASAN}

\section{Hasil Penelitian}

Berdasarkan hasil pengamatan siswa kelas 4 SDN Kutoharjo 01 Pati Kabupaten Pati semester 1 tahun ajaran 2014/2015 pada prasiklus, nampak bahwa pemerolehan hasil belajar siswa di bawah $K K M \geq 80$. Dari 26 siswa, ketuntasan 4 
muatan pelajaran yakni Matematika, Bahasa Indonesia, IPA dan IPS, tidak satupun siswa yang tuntas belajar mencapai $\mathrm{KKM} \geq 80$. Hal ini nampak, pada distribusi frekuensi hasil belajar tematik pra siklus yang disajikan melalui tabel 2.

Tabel 2

Distribusi Frekuensi Hasil Belajar Tema Berbagai Pekerjaan Siswa Kelas 4 SDN Kutoharjo 01 Pati Kabupaten Pati Semester 1 Tahun Ajaran 2014-2015 Pra Siklus

\begin{tabular}{|c|c|c|}
\hline Skor Hasil Belajar & Frekuensi & Persentase (\%) \\
\hline $20-29$ & 3 & 11,54 \\
\hline $30-39$ & 16 & 61,54 \\
\hline $40-49$ & 7 & 26,92 \\
\hline Jumlah & 26 & 100 \\
\hline
\end{tabular}

Sumber: Data Primer

Berdasarkan tabel 2 nampak, bahwa distribusi hasil belajar tema Berbagai Pekerjaan siswa kelas 4 pra siklus nampak tidak merata.

Pelaksanaan penelitian siklus 1 dilakukan dengan melaksanakan tindakan pembelajaran pendekatan discovery learning. Prosedur tindakan penelitian dilaksanakan melalui 3 (tiga) tahapan yakni; 1) perencanaan tindakan; 2) pelaksanaan tindakan dan observasi; dan 3) refleksi.

Dalam tahap perencanaan penelitian siklus 1, kegiatan yang dilakukan meliputi; menyusun RPP beserta perangkat pembelajaran, serta menyiapkan lembar observasi. RPP disusun menggunakan pendekatan discovery learning, dengan tema Berbagai Pekerjaan, sub tema Barang dan Jasa, yang dirancang dalam 2 kali pertemuan dengan alokasi waktu @ 5 x 35 menit. Kompetensi Dasar (KD) yang akan dicapai meliputi 4 mata pelajaran, yaitu KD 3.13., KD 4.9, KD 3.7, KD 4.7., KD 3.1. KD 4.1. KD 3.1. dan KD 4.1.

Perangkat pembelajaran yang dipersiapkan meliputi, materi pelajaran, media dan alat peraga pembelajaran, kisi-kisi penilaian, Lembar Kerja Siswa (LKS), butir-butir soal tes formatif, kunci jawaban dan pedoman penilaian. Sedangkan lembar observasi yang dipersiapkan berupa instrumen observasi pelaksanaan pendekatan discovery learning untuk guru dan respon siswa terhadap tindakan pembelajaran.

Pelaksanaan tindakan penelitian siklus 1, dilaksanakan pada tanggal 18-20 November 2014, melalui 2 kali pertemuan dengan alokasi waktu @ 2 x 35 menit.

Pelaksanaan penelitian siklus 1 dan siklus 2 sesuai RPP. Berdasarkan hasil observasi dan refleksi yang telah dilakukan, nampak bahwa dari 20 butir kegiatan discovery learning, hanya 3 butir kegiatan yang belum dilakukan oleh guru secara sempurna, dan pada siklus 2 , semua tindakan telah dilakukan. 
Berdasarkan hasil tes formatif dan pengamatan terhadap unjuk kerja siswa, yang meliputi kegiatan mengamati, menanya, mengumpulkan informasi, mengklasifikasi dan mengolah data, serta mempresentasikan, diperoleh hasil belajar tematik pada tema Berbagai Pekerjaan, sub tema Barang dan Jasa, yang secara rinci disajikan dalam tabel 3 berikut ini.

\section{Tabel 3}

Distribusi Frekuensi Hasil Belajar Sub Tema Barang Dan Jasa Siswa

Kelas 4 SDN Kutoharjo 01 Pati Kabupaten Pati

Semester 1 Tahun Ajaran 2014-2015 Siklus 1

\begin{tabular}{|c|c|c|}
\hline Skor Hasil Belajar & Frekuensi & Persentase (\%) \\
\hline $50-59$ & 3 & 11,54 \\
\hline $60-69$ & 2 & 7,69 \\
\hline $70-79$ & 3 & 11,54 \\
\hline$\geq 80$ & 18 & 69,23 \\
\hline Jumlah & 26 & 100 \\
\hline
\end{tabular}

Sumber: Data Primer

Berdasarkan tabel 3 diatas, hasil belajar siswa yang mendapat skor antara 50-59 dan 70-79, masing-masing ada 3 siswa (11,54\% dari seluruh siswa), siswa yang mendapat skor antara 60-69 sebanyak 2 siswa (7,69\% dari seluruh siswa), dan siswa yang mendapat skor $\geq 80$ sebanyak 18 siswa $(69,23 \%$ dari 26 siswa). Besarnya skor maksimum, skor minimum dan skor rata-rata hasil belajar siklus 1 secara rinci disajikan melalui tabel 4 berikut ini.

\section{Tabel 4}

Deskripsi Skor Maksimum, Skor Minimum dan Skor Rata-Rata Sub Tema Barang Dan Jasa Siswa Kelas 4 SDN Kutoharjo 01 Pati Kabupaten Pati Semester 1 Tahun Ajaran 2014-2015 Siklus 1

\begin{tabular}{|c|c|}
\hline Deskripsi & Skor \\
\hline Skor Maksimum & 92 \\
\hline Skor Minimum & 53 \\
\hline Skor Rata-Rata & 78,5 \\
\hline
\end{tabular}

Sumber: Data Primer

Berdasar tabel 4, skor maksimum yang diperoleh siswa sebesar 92, skor minimum sebesar 53, dan skor rata-rata sebesar 78,5. Adapun pencapaian hasil belajar siklus 1, berdasarkan ketuntasan belajar sub tema barang dan jasa, pada siklus 1 adalah sebesar 69,23\% (18 siswa) dari seluruh siswa tuntas belajar, dan 
$30,76 \%$ (8 siswa) dari seluruh siswa tidak tuntas belajar. Secara rinci, distribusi ketuntasan belajar tema berbagai pekerjaan disajikan dalam gambar 4 .

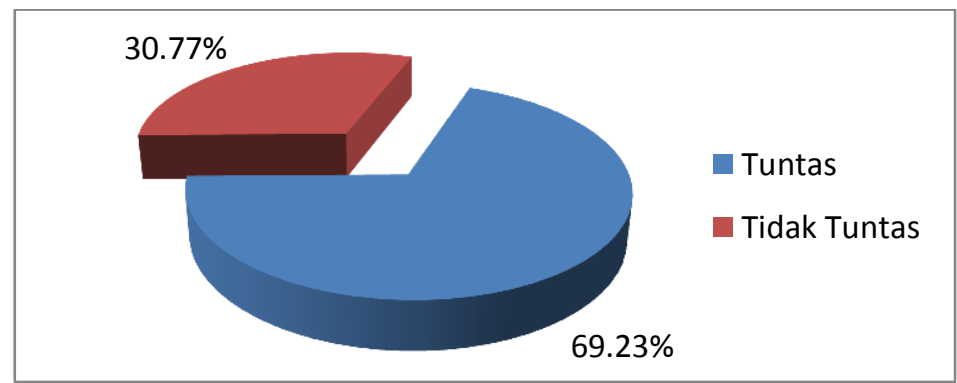

Sumber: Data Primer

\section{Gambar 4}

Diagram Lingkaran Ketuntasan Belajar Sub Tema Barang Dan Jasa

Siswa Kelas 4 SDN Kutoharjo 01 Pati Kabupaten Pati

Semester 1 Tahun Ajaran 2014-2015 Siklus 1

Hasil belajar siswa, berdasarkan ketuntasan belajar siklus 1 belum mencapai indiktor keberhasilan $80 \%$. Hasil belajar dalam siklus 1 baru mencapai $69,23 \%$ dari seluruh siswa,, maka penelitian dilanjutkan ke siklus 2. Hal ini didasarkan pada indikator keberhasilan yang ditetapkan yakni $\geq 80 \%$ siswa tuntas belajar dengan mencapai skor $\mathrm{KKM} \geq 80$.

Pelaksanaan penelitian siklus 2, mengacu pada hasil refleksi yang dilakukan pada siklus 1. Pelaksanaan penelitian siklus 2, dilakukan dengan memberi tindakan pembelajaran menggunakan pendekatan discovery learning. Adapun prosedur penelitian yang dilakukan dalam siklus 2 , adalah sama seperti pada siklus 1 yakni, perencanaan, pelaksanaan tindakan dan observasi, refleksi.

Kegiatan refleksi dilakukan pada akhir kegiatan siklus 2, oleh guru bersama-sama dengan observer. Refleksi dilakukan untuk mengevaluasi dan mengetahui keberhasilan dan kegagalan pelaksanaan pembelajaran tematik siklus 2, dengan tema Berbagai Pekerjaan, sub tema Pekerjaan Orangtuaku.

Berdasarkan hasil observasi siklus 2, menunjukkan bahwa pembelajaran dengan menggunakan pendekatan discovery learning, dapat meningkatkan keaktifan siswa dalam pembelajaran. Hal ini nampak, pada meningkatnya aktifitas siswa dalam kegiatan menyimak, menanya, mengidentifikasi, memgklasifikasi, merumuskan masalah, membuat hipotesa, mengumpulkan informasi, menguji kebenaran hipotesa, menarik kesimpulan dan mempresentasikan. Selain sangat aktif, mengemukakan ide dan pendapatnya dalam kegiatan diskusi. Adapun kelebihan guru, yang menonjol dalam pelaksanaan penelitian siklus 2, adalah guru telah melaksanakan kegiatan pembelajaran melalui pendekatan discovery learning, 
sesuai dengan prinsip dan langkah-langkah discovery learning. Guru juga telah membimbing, mengarahkan dan mendampingi siswa dalam kegiatan discovery learning, dimulai dari kegiatan merumuskan masalah, mengumpulkan informasi sampai dengan generalisasi dan presentasi. Sedangkan kelemahan yang masih Nampak, pada pembelajaran siklus 2, yaitu siswa masih merasa kesulitan untuk memberikan tanggapan terhadap presentasi hasil diskusi. Solusi yang dilakukan oleh guru, adalah dengan memberikan kata kunci, untuk merangsang siswa memberikan pendapat dan tanggapan terhadap laporan hasil diskusi.

Dari hasil tes formatif, dan penilaian terhadap ketrampilan atau unjuk kerja, siswa dalam menyimak, menanya, mengumpulkan informasi, mengklasifikasi, menggeneralisasi dan mempresentasikan, yang dilakukan pada kegiatan pembelajaran siklus 2, menunjukkan adanya peningkatan hasil belajar siswa. Dari 26 siswa, hasil belajar siswa yang memperoleh skor 60-69 sebanyak 1 siswa (3,85\% dari seluruh siswa), siswa yang memperoleh skor 70-79 sebanyak 2 siswa (7,69\% dari seluruh siswa), dan siswa yang memperoleh skor $\geq 80$ sebanyak 17 siswa (88,46\% dari seluruh siswa).

Besar skor maksimum, skor minimum dan skor rata-rata siklus 2, secara rinci disajikan melalui tabel 5 berikut ini.

\section{Tabel 5}

Deskripsi Skor Maksimum, Skor Minimum dan Skor Rata-Rata

Sub Tema Pekerjaan Orang Tuaku Siswa Kelas 4 SDN

Kutoharjo 01 Pati Kabupaten Pati Semester 1

Tahun Ajaran 2014-2015 Siklus 2

\begin{tabular}{|c|c|}
\hline Deskripsi & Skor \\
\hline Skor Maksimum & 100 \\
\hline Skor Minimum & 66 \\
\hline Skor Rata-Rata & 88,0 \\
\hline
\end{tabular}

Sumber: Data Primer

Tabel 5, menunjukkan besarnya skor maksimum siklus 2 yaitu 100, skor minimum 66 dan skor rata-rata sebesar 88,0. Hasil belajar sub tema pekerjaan orang tuaku berdasarkan ketuntasan belajar, sebanyak 23 siswa $(88,46 \%$ dari seluruh siswa), sedangkan siswa yang tidak tuntas belajar sebanyak 3 siswa (11,54\% dari seluruh siswa).

\section{Pembahasan}

Hasil belajar tema berbagai pekerjaan, pada kegiatan pembelajaran pra siklus, siswa dari seluruh siswa, belum mencapai $K K M \geq 80$. Hal ini terlihat pada skor tes, empat muatan pelajaran yang menunjukkan ketuntasan belajar, masih jauh 
dari target Kriteria Ketuntasan Minimal (KKM) yang ditetapkan yaitu $\geq 80 \%$, siswa tuntas belajar dengan mencapai skor $\mathrm{KKM} \geq 80$. Permasalahan yang mengakibatkan rendahnya pencapaian hasil belajar pra siklus, diantaranya adalah pembelajaran belum dilaksanakan dengan menggunakan pendekatan pembelajaran tertentu seperti pendekatan discovery learning; proses penilaian hanya terfokus pada penilaian aspek kognitif, dan belum menyentuh aspek sikap dan ketrampilan (unjuk kerja). Hal ini tidak sesuai dengan sistem penilaian kurikulum 2013, yang menyatakan bahwa dalam pembelajaran tematik, penilaian dilakukan secara menyeluruh, semua aspek meliputi, aspek sikap, aspek pengetahuan dan aspek ketrampilan (unjuk kerja). Wardani Naniek Sulistya, dkk., (2012, 65) menyatakan bahwa salah satu prinsip dasar asesmen pembelajaran tematik adalah komprehensif, artinya asesmen hasil belajar peserta didik harus dilaksanakan secara menyeluruh, utuh, dan tuntas, yang mencakup seluruh domain aspek kognitif, psikomotorik, dan afektif atau nilai, dan ketrampilan, serta materi secara representative, sehingga hasilnya dapat diintegrasikan dengan baik. Pendapat yang sama, juga dikemukakan oleh Bloom dan Kratwohl (dalam Usman, 1994: 29), bahwa hasil belajar merupakan perubahan tingkah laku, yang secara umum dapat dikelompokkan ke dalam tiga kategori yaitu ranah kognitif, afektif, dan psikomotor.

Berdasarkan hasil belajar dan hasil analisis terhadap kelemahan dan kekurangan, selama pembelajaran prasiklus, maka dilakukan penelitian dengan memberi tindakan pembelajaran dengan mengunakan pendekatan discovery learning. Pada akhir setiap tindakan penelitian, dilakukan asesmen pembelajaran menggunakan instrumen penilaian tes dan unjuk kerja. Setelah pelaksanaan penelitian, nampak adanya peningkatan hasil belajar dari pra siklus, siklus 1 dan siklus 2. Peningkatan hasil belajar tersebut, secara rinci disajikan dalam tabel 6 berikut ini.

\section{Tabel 6}

Perbandingan Distribusi Tindakan Pendekatan Discovery Learning Guru dan Siswa Kelas 4 SDN Kutoharjo 01 Pati Kabupaten Pati Semester 1 Tahun Ajaran 2014-2015 Siklus 1 dan Siklus 2

\begin{tabular}{|l|c|c|c|c|}
\hline \multirow{2}{*}{ Kegiatan } & \multicolumn{2}{|c|}{ Guru } & \multicolumn{2}{c|}{ Siswa } \\
\cline { 2 - 5 } & S1 & S2 & S1 & S2 \\
\hline Jumlah kegiatan dilaksanakan & 17 & 20 & 14 & 19 \\
\hline Jumlah kegiatan tidak dilaksanakan & 3 & - & 6 & 1 \\
\hline Jumlah & 20 & 20 & 20 & 20 \\
\hline
\end{tabular}

Sumber: Data Primer 
Dari tabel 6 diatas, nampak peningkatan aktifitas guru dalam melaksanakan tindakan discovery learning dari siklus 1 ke siklus 2. Pada siklus 1, dari 20 butir kegiatan discovery learning yang sudah dilaksanakan guru sebanyak 19 (86,36\% dari 20 butir) butir kegiatan, dan 3 butir $(13,64 \%)$ masih belum dilaksanakan oleh guru. Selanjutnya, pada pembelajaran siklus 2, seluruh kegiatan pelaksanaan tindakan discovery learning sudah dilakukan oleh guru. Sedangkan respon siswa terhadap pelaksanaan discovery learning, pada siklus 1 sebanyak 14 butir $(70,0 \%)$ kegiatan sudah dilaksanakan, dan $6(30,0 \%)$ butir lainnya belum dilaksanakan. Pada siklus 2 jumlah kegiatan yang sudah dilaksanakan siswa meningkat menjadi 19 butir, dan hanya 1 butir yang tidak dilaksanakan oleh siswa. Peningkatan respon siswa terhadap tindakan discovery learning sebanyak 19 butir dari 20 butir kegiatan, menunjukkan kelebihan siswa, dan keberhasilan guru dalam melaksanakan tindakan discovery learning.

Setelah dilakukan penelitian dengan mengoptimalkan pelaksanaan tindakan discovery learning pada siklus 1 dan 2, maka hasil belajar meningkat secara signifikan. Hal ini ditunjukkan, oleh meningkatnya ketuntasan belajar dari prasiklus, siklus 1 dan siklus 2 . Berdasarkan peningkatan hasil belajar yang dicapai pada pembelajaran pra siklus, siklus 1 dan siklus 2, dapat diketahui perbandingan hasil belajar tema Berbagai Pekerjaan, berdasarkan ketuntasan belajar pra siklus, siklus 1 dan siklus 2, siswa kelas 4 SDN Kutoharjo 01 Pati Kabupaten Pati semester 1 tahun ajaran 2014-2015, yang secara rinci disajikan dalam tabel 7 dan gambar 5 berikut ini.

\section{Tabel 7}

Perbandingan Hasil Belajar Tema Berbagai Pekerjaan Berdasarkan Ketuntasan Belajar Siswa Pra Siklus, Siklus 1 dan Siklus 2

\begin{tabular}{|c|c|c|c|c|c|c|}
\hline Ketuntasan & \multicolumn{2}{|c|}{ Pra Siklus } & \multicolumn{2}{c|}{ Siklus 1 } & \multicolumn{2}{c|}{ Siklus 2 } \\
\hline Belajar & $\mathrm{f}_{\mathrm{i}}$ & $\%$ & $\mathrm{f}_{\mathrm{i}}$ & $\%$ & $\mathrm{f}_{\mathrm{i}}$ & $\%$ \\
\hline Tuntas & 0 & 0 & 18 & 69,23 & 23 & 88,46 \\
\hline Tidak Tuntas & 26 & 100 & 8 & 30,76 & 3 & 11,54 \\
\hline Jumlah & 26 & 100 & 26 & 100 & 26 & 100 \\
\hline
\end{tabular}

Sumber: Data Primer

Berdasarkan tabel 7, nampak bahwa ketuntasan belajar pra siklus, tidak ada satupun siswa yang tuntas belajar mencapai $\mathrm{KKM} \geq 80$. Kemudian setelah dilakukan tindakan discovery learning pada siklus 1, siswa yang mencapai ketuntasan belajar meningkat menjadi 69,23\% (18 siswa) dari seluruh siswa. Selanjutnya pada akhir siklus 2 , siswa yang mencapai ketuntasan belajar meningkat menjadi 88,46\% (23 siswa) dari seluruh siswa, yang disajikan melalui gambar 6 diagram batang perbandingan hasil belajar tema berbagai pekerjaan berdasarkan 
ketuntasan belajar siswa kelas 4 SDN Kutoharjo 01 Pati Kabupaten Pati semester 1 tahun ajaran 2014-2015, pra siklus, siklus 1 dan siklus 2 berikut ini.

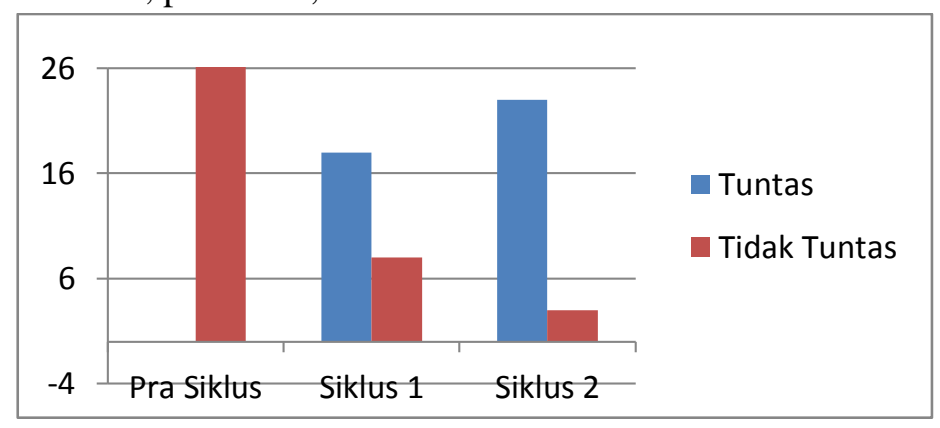

Sumber: Data Primer

\section{Gambar 6}

Diagram Batang Perbandingan Hasil Belajar Tema Berbagai Pekerjaan Berdasarkan Ketuntasan Belajar Siswa

Pra Siklus, Siklus 1 dan Siklus 2

Berdasarkan gambar 6, nampak bahwa ketuntasan belajar siswa kelas 4 SDN Kutoharjo 01 Pati Kabupaten Pati pada kegiatan pra siklus, semula tidak ada siswa yang tuntas belajar, pada siklus 1, siswa yang mencapai ketuntasan belajar sebesar $69,23 \%$ dari seluruh siswa, dan selanjutnya pada akhir siklus 2 siswa yang mencapai ketuntasan belajar meningkat menjadi 88,46\% dari seluruh siswa.

Peningkatan hasil belajar dapat ditinjau dari besarnya skor maksimum, skor minimum dan skor rata-rata, yang ditunjukkan melalui gambar 7 berikut ini.

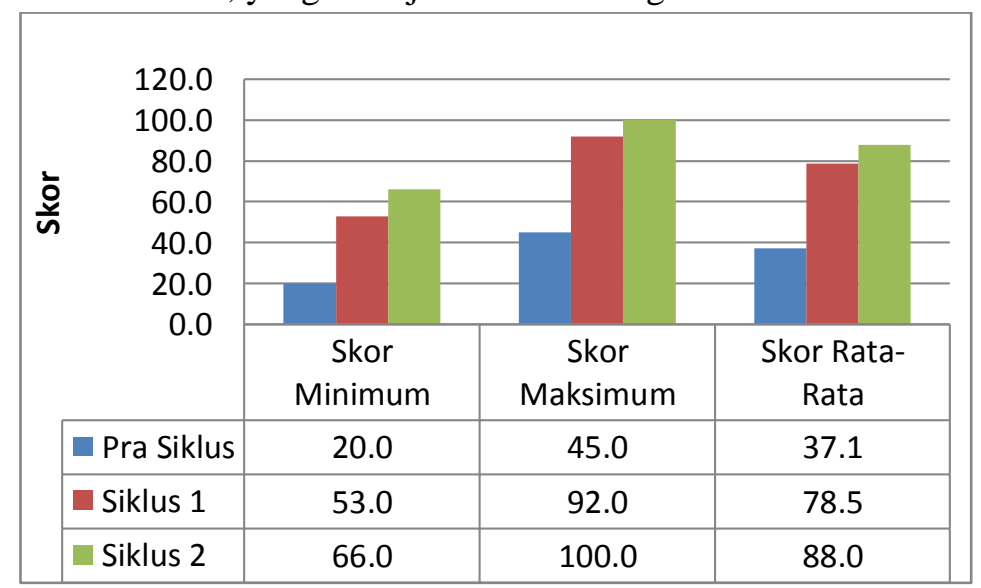

Sumber: Data Primer

\section{Gambar 7}

Diagram Batang Perbandingan Hasil Belajar Tema Berbagai Pekerjaan

Berdasarkan Skor Maksimum, Skor Minimum dan

Skor Rata-Rata Siswa Pra Siklus, Siklus 1 dan Siklus 2 
Dari gambar 47 diatas, nampak peningkatan hasil belajar tema Berbagai Pekerjaan, siswa kelas 4 SDN Kutoharjo 01 Kabupaten Pati. Peningkatan hasil belajar tersebut, nampak dari peningkatan besarnya skor maksimum, skor minimum dan skor rata-rata dari pra siklus, siklus 1 dan siklus 2. Pada pra siklus besarnya skor maksimum yang dicapai siswa adalah 45 , skor minimum 20 dan skor rata-rata sebesar 37,1. Pada siklus 1 perolehan skor maksimum meningkat menjadi 92, skor minimum meningkat menjadi 53 dan skor rata-rata meningkat menjadi 78,5. Selanjutnya pada akhir pembelajaran siklus 2 , skor maksimum mencapai 100, skor minimum sebesar 66, dengan skor rata-rata mencapai 88,0.

Berdasarkan uraian pembahasan hasil penelitian diatas, terbukti bahwa tindakan penelitian yang berupa pendekatan discovery learning dapat meningkatkan kemampuan siswa dalam menyimak, menanya, mengidentifikasi, mengklasifikasi, mengolah data, merumuskan masalah, membuat hipotesa, mengumpulkan informasi, menarik kesimpulan dan mempresentasikan. Peningkatan aktivitas belajar siswa berdampak positif terhadap hasil belajar tema berbagai pekerjaan, siswa kelas 4 SDN Kutoharjo 01 Pati semester 1 tahun ajaran 2014-2015 yang ditunjukkan dengan ketuntasan belajar pada siklus 2 sebesar 88,46\% dari 26 siswa.

\section{SIMPULAN DAN SARAN}

\section{Simpulan}

Berdasarkan hasil penelitian dan pembahasan, maka simpulan yang didapat adalah bahwa peningkatan hasil belajar tema Berbagai Pekerjaan dapat diupayakan melalui pendekatan discovery learning siswa kelas 4 SDN Kutoharjo 01 Pati Kabupaten Pati 2015, terbukti. Hal ini ditunjukkan dengan adanya peningkatan hasil belajar tema berbagai pekerjaan berdasarkan ketuntasan belajar pra siklus, siklus 1 dan siklus 2 yakni $0 \% ; 69,23 \%$ dan 88,46\%. Peningkatan hasil belajar berdasarkan skor maksimum berturut-turut sebesar 45; 92; dan 100. Peningkatan hasil belajar berdasarkan skor minimum sebesar 20, 53 dan 66. Peningkatan hasil belajar berdasarkan skor rata-rata sebesar 37,1; 78,5; dan 88,0. Keberhasilan penelitian ini ditunjukkan oleh pencapaian ketuntasan hasil belajar siswa (dengan $\mathrm{KKM} \geq 80$ ) pada siklus 2 mencapai $88,46 \%$ dari seluruh siswa. Capaian ini lebih tinggi dari target $80 \%$ yang ditetapkan.

\section{Saran}

Berdasarkan hasil penelitian, pembahasan serta simpulan PTK ini, disarankan: 
1. Guru hendaknya dapat mendesain dan melaksanakan pembelajaran melalui pendekatan discovery learning Dan meningkatkan profesi pembelajarannya melalui penelitian tindakan kelas.

2. Hendaknya Kepala sekolah selalu memberikan motivasi kepada guru untuk meningkatkan kualitas pembelajaran dengan mendesain pembelajaran dengan pendekatan discovery learning. Selain itu kepala sekolah, sebaiknya juga memberikan apresiasi dan pernghargaan, kepada guru dan siswa yang telah berhasil, mencapai hasil (output) pembelajaran sesuai target yang di tetapkan.

3. Bagi siswa yang belum mencapai ketuntasan belajar, disarankan untuk mengikuti bimbingan dan remidi yang diberikan oleh guru. Setelah mengikuti discovery learning, siswa juga harus selalu aktif dalam mencari informasi berkaitan dengan materi pelajaran dengan cara membaca buku-buku diperpustakaan untuk menemukan pengalaman dan pengetahuan yang baru.

\section{DAFTAR PUSTAKA}

Anonim. 2013. Bahan Ajar Pengelolaan Pembelajaran Tematik Terpadu. Kementerian Pendidikan dan Kebudayaan. Jakarta: Badan Pengembangan Sumber Daya Manusia Pendidikan Dan Kebudayaan Dan Penjaminan Mutu Pendidikan Pusat Pengembangan Tenaga Kependidikan.

Anonim. 2013. Model Pembelajaran Penemuan (Discovery Learning). Kementerian Pendidikan dan Kebudayaan. Jakarta: Badan Pengembangan Sumber Daya Manusia Pendidikan Dan Kebudayaan Dan Penjaminan Mutu Pendidikan.

Anonim. 2013. Salinan Lampiran Peraturan Menteri Pendidikan dan Kebudayaan Republik Indonesia Nomor 66 Tahun 2013 tentang Standar Penilaian Pendidikan. Jakarta: Berita Negara Republik Indonesia Tahun 2013

Anonim. 2013. Salinan Lampiran Peraturan Menteri Pendidikan Dan Kebudayaan Nomor 67 Tahun 2013 Tentang Kerangka Dasar Dan Struktur Kurikulum Sekolah Dasar/Madrasah Ibtidaiyah.

Cronbach, Lee J. 1990. Essentials of Psycological Testing. Fit Edition. New York: Harper and Row Publisers

Rasyid, Harun dan Mansyur. 2008. Penilaian Hasil Belajar. Bandung: CV. Wacana Prima.

Rizqi. 2000. Pengembangan Perangkat Pembelajaran Berorientasi Pembelajaran Penemuan Terbimbing (Guide-Discovery Learning) yang Mengintegrasikan Kegiatan Laboratorium untuk Fisika SLTP Bahan Kajian Pengukuran. Tesis. Surabaya: UNESA.

Sanjaya, Wina. 2007. Kajian Kurikulum dan Pembelajaran. Bandung: UPI 
Upaya Peningkatan Hasil Belajar Tema Berbagai Pekerjaan Melalui Model Discovery Learning Siswa Kelas 4 SDN Kutoharjo 01 Pati (Rumini \& Naniek Sulistya Wardani)

Sardiman, A.M. 2005, Interaksi dan Motivasi Mengajar. Jakarta : Raja Grafindo Persada, 1994 hlm 22-23)

Syah, M. 1996. Psikologi Pendidikan Suatu Pendekatan Baru. Bandung: PT Remaja Rosdakarya,

Sumarno, Alim. 2011. Pengertian Hasil Belajar, (On Line) (http://elearning. unesa.ac.id/tag/teori-hasil-belajar-gagne-dan-driscoll-dalam-buku-apa di akses 21/10/2014 Pukul 22:39 Wit)

Taruh, Enos. 2003. Konsep Diri dan Motivasi Berprestasi dalam Kaitannya dengan Hasil Belajar Fisika. Jurnal Penelitian dan Pendidikan (hlm.15-29). Gorontalo: IKIP Negeri Gorontalo.

Undang-Undang Republik Indonesia Nomor 20 Tahun 2003 tentang Sistem Pendidikan Nasional. Pasal 1. 2003. Jakarta: Sekretaris Negara RI

Wardani, Naniek Sulistya, dkk. 2012. Asesmen pembelajaran SD. Salatiga : Widya Sari Press

Wardani Naniek Sulistya dan Slameto. 2012. Evaluasi Proses dan Hasil Belajar. Salatiga : Widya Sari.

Waters, R and Mc. Cracken, M. 200. Assessment and Evaluation In Problem Based Learning. Georgia Intitute of Technoloy : Georgia. [online]. Tersedia : http:// [22- 03 -2007]. 